\title{
Dietary fibre intake and risk of breast cancer: A systematic review and meta-analysis of epidemiological studies
}

\author{
Sumei Chen ${ }^{1, *}$, Yuanyuan Chen ${ }^{1, *}$, Shenglin Ma ${ }^{2,3}$, Ruzhen Zheng ${ }^{1}$, Pengjun Zhao ${ }^{1}$, \\ Lidan Zhang ${ }^{1}$, Yuehua Liu ${ }^{1}$, Qingqing Yu ${ }^{1}$, Qinghua Deng ${ }^{1,2}$, Ke Zhang ${ }^{1}$ \\ ${ }^{1}$ Department of Radiation Oncology, Hangzhou Cancer Hospital, Hangzhou, Zhejiang 310002, China \\ ${ }^{2}$ Affiliated Hangzhou First People's Hospital, Hangzhou, Zhejiang 310006, China \\ ${ }^{3}$ Affiliated Hangzhou Hospital of Nanjing Medical University, Hangzhou, Zhejiang 310006, China \\ *These authors contributed equally to this work
}

Correspondence to: Ke Zhang, email: scitificwork@163.com

Qinghua Deng, email: wordhail@163.com

Keywords: breast cancer, dietary fibre, meta-analysis, epidemiology

Received: July 05, 2016 Accepted: October 27, $2016 \quad$ Published: November 05, 2016

\section{ABSTRACT}

Current evidence from randomised controlled trials on the effects of dietary fibre intake on breast cancer risk is inconsistent. We conducted a meta-analysis to determine the effectiveness of dietary fibre intake in reducing breast cancer risk. We searched for prospective and case-control studies on dietary fibre intake and breast cancer risk in the English language through March 2016. Twenty-four epidemiologic studies obtained through the PubMed, Embase, Web of Science, and Cochrane Library databases were systematically reviewed. A random-effects model was used to compute the pooled risk estimates by extracting the risk estimate of the highest and lowest reported categories of intake from each study. The meta-analyses showed a $12 \%$ decrease in breast cancer risk with dietary fibre intake. The association between dietary fibre intake and breast cancer risk was significant when stratified according to Jadad scores, study types, and menopause status. Dose-response analysis showed that every $10 \mathrm{~g} / \mathrm{d}$ increment in dietary fibre intake was associated with a $4 \%$ reduction in breast cancer risk, and little evidence of publication bias was found. Thus, dietary fibre consumption is significantly associated with a reduced risk of breast cancer, particularly in postmenopausal women.

\section{INTRODUCTION}

Breast carcinoma is the most common carcinoma in women worldwide. Ecological and migrant studies have provided strong evidence that environmental factors, including lifestyle and dietary factors, are related to breast carcinoma risk [1-3]. For example, when women who previously lived in countries with a low risk for breast cancer immigrated to high-risk countries, their risk of developing breast cancer increased [4].

Epidemiological studies have shown conflicting results for the relationship between intake of dietary fibre and breast cancer. Dietary fibre reduce the risk of breast cancer may likely by decreasing the level of estrogen in the blood circulation [5]. Results of the most recent meta-analysis published in 2012, which included 17 publications, supported this hypothesis [6]. However, there have been a lot of recent prospective cohort studies [7-22] on dietary fibre intake and breast cancer, and most of the results show that the association between the two is not significant. Recently, several studies [23-30] observed the vital negative correlation between the two. The protective effect of dietary fibre intake on breast cancer risk have been reported in some cohort studies $[15,20$, 27-30], whereas others reported no effect or even a positive association [7-14, 16-19, 21-26]. Due to the difficulties in obtaining precise estimates of intakes of dietary fibre and owing to the limited heterogeneity of fibre intake within geographically confined populations, the results of these analytical epidemiological studies were conflicting.

Thus, our aim was to clarify the two in a large, geographically and culturally heterogeneous cohort. Pre-specific stratified analyses were performed to assess the impact of various study characteristics on outcomes. 
We also evaluated whether a dose-response relationship existed between the two.

\section{RESULTS}

\section{Studies and characteristics}

We selected 24 articles from the 47 studies, Which on the relationship between dietary fibre intake and breast cancer (Figure 1). A total of 51,939 cases and 3,662,421 participants were included. All studies included were population-based and their characteristics are listed in Table 1. In this table, a total of eight studies from the United States, two in Canada, twelve in Europe, one in China, and one in Malaysia. The ranges of dietary fibre intake were comparable in most studies, except three studies $[11,18,28]$. Most of the studies have extensively adjusted the potential confounding factors of breast cancer, including smoking; age; body mass index; total energy intake; family history of cancer.

\section{Main results}

Figure 2 showed a positive association between dietary fibre intake and risk of breast cancer of the twentyfour selected studies. Overall, for the final RR was 0.88 (95\% CI: $0.83-0.93)$. The heterogeneity across studies is acceptable $\left(P=0, I^{2}=59.1 \%\right)$. Figure 3 certified that the publication dates were similar. The meta regulation test showed that geographical area was associated with $\sim 23.4 \%$ heterogeneity reduction across the studies (Figure 4).

\section{Subgroup and sensitivity analyses}

Table 2 shows the results of the subgroup analyses according to menopausal status, Jadad score, influence factors, study types, and geographic region. There were no evidence of heterogeneity in case-control studies, postmenopausal women, and with a Jadad score of 3/5 among all influence factors and geographic regions. The association between dietary fibre intake and breast cancer risk will not alter for geographic area, duration of followup, and menopausal status. Sensitivity analysis was to investigate a single study on the overall risk assessment. All combined RRs were statistically significant and similar to one another, and the geographical area was associated with an approximately $48.6 \%$ reduction in heterogeneity across studies.

\section{Dose-response analysis}

Since the data required in the three studies are not provided $[11,18,28]$, we performed a dose response analysis for the rest of the study. Overall, dietary fibre intake increased by $10 \mathrm{~g} / \mathrm{D}$, with a $4 \%$ reduction in breast cancer risk (RR: $0.96 ; 95 \%$ CI: $0.92-0.98 ; P=0.002$ ), and the heterogeneity was not observed $(P=0.43)$.

\section{Publication bias}

We performed Begg's test and Egger's test in all studies. They both indicated little evidence of publication bias $(P>0.05$; Figures 5 and 6$)$.

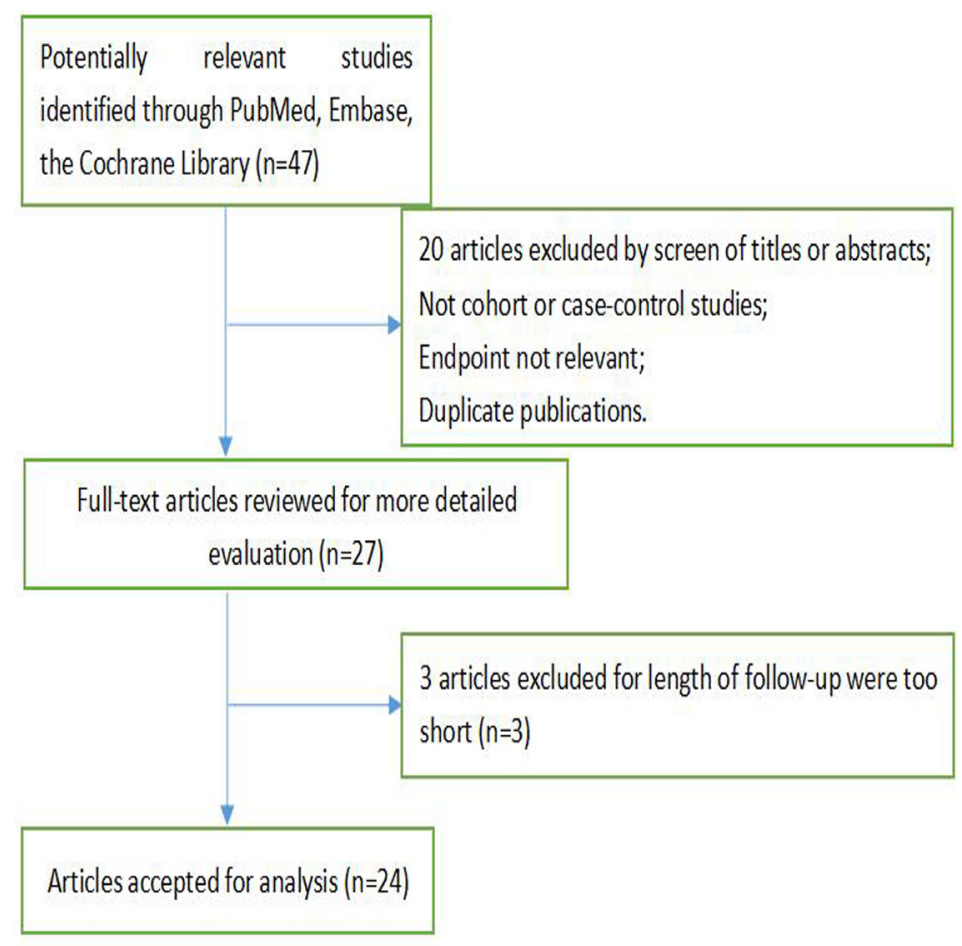

Figure 1: Search strategy and selection of studies. 
Table 1: Characteristics of the studies included in the meta-analysis

\begin{tabular}{|c|c|c|c|c|c|c|c|c|c|c|}
\hline Study & Year & $\begin{array}{l}\text { Menopause } \\
\text { status }\end{array}$ & $\begin{array}{l}\text { Geographic } \\
\text { area }\end{array}$ & Duration & Age range & $\begin{array}{l}\text { No. of cases/ } \\
\text { sample size }\end{array}$ & $\begin{array}{l}\text { Exposure } \\
\text { range }(g / d)\end{array}$ & $\begin{array}{l}\text { Adjusted RR } \\
(95 \% \mathrm{CI})\end{array}$ & Adjustment for covariates & $\begin{array}{l}\text { Jadad } \\
\text { score }\end{array}$ \\
\hline $\begin{array}{l}\text { Graham et } \\
\text { al. }\end{array}$ & 1992 & Postmenopause & USA & $1980-1987$ & $40-107$ y & $344 / 18,586$ & $\begin{array}{l}\text { Q5: }>32.7 \\
\text { Q1: }<16\end{array}$ & $1.07(0.76-1.51)$ & Age, education & 4 \\
\hline Kushi et al. & 1992 & Postmenopause & Switzerland & 1986-1989 & $55-69 y$ & $459 / 34,388$ & $\begin{array}{l}\text { Q5: } 27.0 \\
\text { Q1: } 14.1\end{array}$ & $0.99(0.74-1.31)$ & $\begin{array}{l}\text { Age, age at menopause, age at first birth, family } \\
\text { history of breast cancer, body mass index, BMI at } \\
\text { age } 18 \text { years, waist-to-hip ratio, history of benign } \\
\text { breast disease, alcohol intake, total energy intake }\end{array}$ & 4 \\
\hline $\begin{array}{l}\text { Verhoeven } \\
\text { et al. }\end{array}$ & 1997 & Postmenopause & Netherlands & $1986-1990$ & $55-69 \mathrm{y}$ & $650 / 62,573$ & $\begin{array}{l}\text { Q5: } 34.5 \\
\text { Q1: } 16.9\end{array}$ & $\begin{array}{l}0.83 \\
(0.56-1.24)\end{array}$ & $\begin{array}{l}\text { Age; energy intake; alcohol intake; history of } \\
\text { benign breast disease; family history of breast } \\
\text { cancer; parity; age at menarche, menopause, first } \\
\text { birth }\end{array}$ & 3 \\
\hline Terry et al. & 2002 & Not specified & Canada & 1980-2000 & $40-59 y$ & $2,536 / 89,835$ & $\begin{array}{l}\text { Q5: }>25.8 \\
\text { Q1: }<15.2\end{array}$ & $\begin{array}{l}0.92 \\
(0.78-1.09)\end{array}$ & $\begin{array}{l}\text { Age; BMI; smoking; education; physical activity; } \\
\text { oral contraceptive use; HRT use; parity; history of } \\
\text { benign } \\
\text { breast disease; history of breast self-examination; } \\
\text { family history of breast cancer; menopausal status, } \\
\text { intakes of energy, alcohol, saturated fat. }\end{array}$ & 4 \\
\hline $\begin{array}{l}\text { Horn-Ross } \\
\text { et al. }\end{array}$ & 2002 & Not specified & USA & 1995-1996 & $21-103 y$ & $711 / 111,526$ & $\begin{array}{l}\text { highest; } \\
\text { lowest }\end{array}$ & $1.1(0.8-1.4)$ & $\begin{array}{l}\text { Age, race, daily caloric intake, family history of } \\
\text { breast cancer, age at menarche, nulliparity/age at } \\
\text { first full-term pregnancy, } \\
\text { physical activity, an interaction term for BMI and } \\
\text { menopausal status }\end{array}$ & 3 \\
\hline Sieri $\mathrm{S}$ et al. & 2002 & Postmenopause & Italian & 1987-1992 & $41-70 y$ & $56 / 3,367$ & $\begin{array}{l}\text { Q5: }>20.1 ; \\
\text { Q1: }<16.6\end{array}$ & $0.73(0.33-1.59)$ & $\begin{array}{l}\text { Energy, parity, place of birth, level of education, } \\
\text { total carbohydrates }\end{array}$ & 3 \\
\hline Cho et al. & 2003 & Premenopause & USA & 1991-1999 & $26-46 y$ & $714 / 90,655$ & $\begin{array}{l}\text { Q5: } 24.8 \\
\text { Q1: } 12.5\end{array}$ & $\begin{array}{l}0.88 \\
(0.67-1.14)\end{array}$ & $\begin{array}{l}\text { Age, smoking, height, parity and age at first } \\
\text { birth, BMI, age at menarche, family history of } \\
\text { breast cancer, history of benign breast disease, } \\
\text { oral contraceptive use, menopausal status, alcohol } \\
\text { intake, energy intake, animal fat intake }\end{array}$ & 4 \\
\hline $\begin{array}{l}\text { Holmes et } \\
\text { al. }\end{array}$ & 2004 & Not specified & USA & $1980-1998$ & $34-59 y$ & $4,092 / 88,678$ & $\begin{array}{l}\text { Q5: }>30 \\
\text { Q1: }<10\end{array}$ & $\begin{array}{l}0.68 \\
(0.43-1.06)\end{array}$ & $\begin{array}{l}\text { Age, BMI, total energy intake, alcohol intake, } \\
\text { parity and age at first birth, height, family history } \\
\text { of breast cancer, history of benign breast disease, } \\
\text { age at menarche (y), HRT use, menopausal status }\end{array}$ & 5 \\
\hline Cade et al. & 2007 & Premenopause & $\begin{array}{l}\text { United } \\
\text { Kingdom }\end{array}$ & 1995-2004 & $35-50 y$ & $257 / 15,951$ & $\begin{array}{l}\text { Q5: }>30 \\
\text { Q1: }<20\end{array}$ & $\begin{array}{l}0.48 \\
(0.24-0.96)\end{array}$ & $\begin{array}{l}\text { Age, BMI, physical activity, smoking, oral } \\
\text { contraceptive use, number of children, alcohol } \\
\text { intake, total energy intake }\end{array}$ & 5 \\
\hline $\begin{array}{l}\text { Sonestedt } \\
\text { et al. }\end{array}$ & 2008 & Not specified & Sweden & 1991-2004 & $46-75 y$ & $544 / 15,773$ & $\begin{array}{l}\text { Q5: } 26.0 \\
\text { Q1: } 12.0\end{array}$ & $\begin{array}{l}0.82 \\
(0.61-1.09)\end{array}$ & $\begin{array}{l}\text { Age, season of data collection, diet interviewer, } \\
\text { method version, total energy, weight, height, } \\
\text { education, smoking, physical activity, household } \\
\text { activities, alcohol intake, age at menopause, HRT } \\
\text { use }\end{array}$ & 5 \\
\hline $\begin{array}{l}\text { Suzuki } \\
\text { et al. }\end{array}$ & 2008 & Postmenopause & Sweden & $1987-1997$ & $39-73$ y & $1,284 / 51,823$ & $\begin{array}{l}\text { Q5: } 29.0 \\
\text { Q1: } 16.6\end{array}$ & $\begin{array}{l}0.85 \\
(0.69-1.05)\end{array}$ & $\begin{array}{l}\text { Age, height, BMI, education, parity, menopausal } \\
\text { status, oral contraceptive use, HRT use, family } \\
\text { history of breast cancer, history of benign breast } \\
\text { disease, total energy intake, total fat intake, fruit } \\
\text { and vegetable intake, alcohol intake, and age at } \\
\text { first birth, menarche, and menopause. }\end{array}$ & 4 \\
\hline Maruti et al. & 2008 & Not specified & USA & $2000-2002$ & $50-76$ y & $507 / 28,586$ & $\begin{array}{l}\text { highest; } \\
\text { lowest }\end{array}$ & $\begin{array}{l}1.14 \\
(0.82-1.60)\end{array}$ & $\begin{array}{l}\text { Age, race, mother/sister with breast cancer, } \\
\text { mammography within } 2 \text { y preceding baseline, } \\
\text { history of breast biopsy, age at menarche, age at } \\
\text { first birth, age at menopause, combined oestrogen } \\
\text { and progestin PMH use, BMI at baseline, past-year } \\
\text { alcohol intake, height, and physical activity in past } \\
10 \mathrm{y} \text {, total energy intake }\end{array}$ & 4 \\
\hline Lajous et al. & 2008 & Postmenopause & French & 1993-2002 & $46-61$ y & $1,812 / 62,739$ & $\begin{array}{l}\text { Q4:35.2; } \\
\text { Q1:15.4 }\end{array}$ & $0.99(0.85,-.16)$ & Total energy intake & 4 \\
\hline Park et al. & 2009 & Postmenopause & USA & 1995-2003 & $50-71$ y & $5,461 / 185,598$ & $\begin{array}{l}\text { Q5: 26.0; } \\
\text { Q1: 11.0 }\end{array}$ & $\begin{array}{l}0.87 \\
(0.77-0.98)\end{array}$ & $\begin{array}{l}\text { Age, race, education, BMI, age at first birth, } \\
\text { family history of breast cancer, age at menopause, } \\
\text { physical activity, smoking, HRT use, breast biopsy, } \\
\text { gynecologic surgery, alcohol intake, total fruit } \\
\text { and vegetable intake, total fat intake, total energy } \\
\text { intake }\end{array}$ & 5 \\
\hline Wen et al. & 2009 & Not specified & China & $1997-2005$ & $40-70 y$ & $616 / 74,942$ & $\begin{array}{l}\text { Q5: 16.3; } \\
\text { Q1: } 7.7\end{array}$ & $\begin{array}{l}1.09 \\
(0.84-1.40)\end{array}$ & $\begin{array}{l}\text { Age, total energy intake, education, BMI, age at } \\
\text { first birth, family history of breast cancer, personal } \\
\text { history of benign breast disease, physical activity }\end{array}$ & 4 \\
\hline $\begin{array}{l}\text { Shikany et } \\
\text { al. }\end{array}$ & 2011 & Postmenopause & USA & $1993-1998$ & $50-79 y$ & $6,115 / 148,767$ & $\begin{array}{l}\text { Q5:25.1; } \\
\text { Q1:8.2 }\end{array}$ & $\begin{array}{l}0.93 \\
(0.82-1.07)\end{array}$ & $\begin{array}{l}\text { Age, ethnicity, education, HRT, Dietary } \\
\text { Modification trial randomisation, Calcium and } \\
\text { Vitamin D trial randomisation, smoking, alcohol, } \\
\text { physical activity, BMI, age at menarche, age at } \\
\text { first birth, age at menopause, oral contraceptive } \\
\text { use, postmenopausal hormone use, breast cancer in } \\
\text { first-degree relative, mammogram within } 2 \text { y prior } \\
\text { to enrollment, energy intake }\end{array}$ & 5 \\
\hline $\begin{array}{l}\text { Zaineddin } \\
\text { et al. }\end{array}$ & 2012 & Postmenopause & German & $2001-2005$ & $50-74 \mathrm{y}$ & $2,884 / 5,509$ & $\begin{array}{l}\text { Q4:24.2; } \\
\text { Q1:16.3 }\end{array}$ & $\begin{array}{l}0.96 \\
(0.94-1.33)\end{array}$ & $\begin{array}{l}\text { Menopausal status, BMI, education level, first- } \\
\text { degree family history of breast cancer, history } \\
\text { of benign breast disease, number of pregnancies } \\
\text { ( } \geq 28 \text { th wk), age at menarche, breastfeeding history, } \\
\text { total number of mammograms, smoking habit, } \\
\text { alcohol consumption, phytoestrogen supplement } \\
\text { use, energy intake, fibre intake }\end{array}$ & 3 \\
\hline Ferrari et al. & 2013 & Not specified & European & 1993-2008 & $35-70 \mathrm{y}$ & $11,576 / 334,849$ & $\begin{array}{l}\text { Q5: } 26.3 ; \\
\text { Q1:<, 17.6 }\end{array}$ & $\begin{array}{l}0.95 \\
(0.89-1.01)\end{array}$ & $\begin{array}{l}\text { Baseline menopausal status, weight, interaction } \\
\text { term between weight and baseline menopausal } \\
\text { status, height, smoking status, schooling level, } \\
\text { physical activity, age at menarche, age at first full- } \\
\text { term birth, ever use of a contraceptive pill, ever } \\
\text { use of hormones, age at menopause, energy intake, } \\
\text { alcohol intake }\end{array}$ & 5 \\
\hline
\end{tabular}




\begin{tabular}{|c|c|c|c|c|c|c|c|c|c|}
\hline $\begin{array}{l}\text { Deschasaux } \\
\text { M et al. }\end{array}$ & 2013 & Not specified & French & 1994-2007 & $40-54$ y & $167 / 4,684$ & $\begin{array}{l}\text { Q4:84.2; } \\
\text { Q1:63.9 }\end{array}$ & $\begin{array}{l}1.29 \\
(0.66-2.5)\end{array}$ & $\begin{array}{l}\text { Age (time scale), intervention group, smoking } \\
\text { status, educational level, physical activity, } \\
\text { height, BMI, number of dietary records, } \\
\text { without-alcohol energy intake, alcohol intake, } \\
\text { total fat intake, overall healthy dietary pattern, } \\
\text { family history of breast cancer, menopausal } \\
\text { status at baseline, number of children }\end{array}$ \\
\hline Li et al. & 2013 & Not specified & French & 1994-1997 & $30-79 y$ & $557 / 1,093$ & $\begin{array}{l}\text { Q4: }>18.3 \\
\text { Q1: }<10.7\end{array}$ & $\begin{array}{l}1.17 \\
(0.76-1.80)\end{array}$ & $\begin{array}{l}\text { Age, race, BMI, age at first menarche, menopausal } \\
\text { status, family history of breast cancer, age at first } \\
\text { full-term birth, months of lifetime breast feeding, } \\
\text { cigarette smoking, alcohol drinking, menopausal } \\
\text { status, total energy intake }\end{array}$ \\
\hline $\begin{array}{l}\text { Sulaiman } \\
\text { et al. }\end{array}$ & 2014 & Not specified & Malaysia & 2006-2007 & $18-80 \mathrm{y}$ & $382 / 1,040$ & $\begin{array}{l}\text { Q4:25; } \\
\text { Q1:16 }\end{array}$ & $\begin{array}{l}0.31 \\
(0.12-0.79)\end{array}$ & $\begin{array}{l}\text { Age, ethnicity, marital status, education, working } \\
\text { status, household income, age of menarche, } \\
\text { age of menopause, pregnancy history, age at } \\
\text { first childbirth, number of live birth, history of } \\
\text { breastfeeding, duration of breastfeeding, history } \\
\text { of oral contraceptive usage, history of HRT usage, } \\
\text { smoking habits, alcohol consumption, physical } \\
\text { activity level, family history of breast cancer, BMI } \\
\text { energy intake }\end{array}$ \\
\hline $\begin{array}{l}\text { Bradbury } \\
\text { et al. }\end{array}$ & 2014 & Not specified & European & $1992-2000$ & Null & $4,517 />500,000$ & $\begin{array}{l}\text { highest } \\
\text { compared with } \\
\text { lowest quintile }\end{array}$ & $\begin{array}{l}0.93 \\
(0.87-0.99)\end{array}$ & Total energy intake \\
\hline Liu et al. & 2014 & Postmenopause & Canada & $2002-2003$ & $25-74$ y & $2,865 / 6,164$ & $\begin{array}{l}\text { Q5: }>13.4 \\
\text { Q1: }<5.2\end{array}$ & $\begin{array}{l}0.66 \\
(0.55-0.78)\end{array}$ & $\begin{array}{l}\text { Total dietary fibre intake } 2 \text { y before study } \\
\text { enrollment; intakes of vegetable protein and } \\
\text { vegetable fat during adolescence further adjusted } \\
\text { for vegetable intake } 2 \text { y before study enrollment }\end{array}$ \\
\hline Farvid et al. & 2016 & Premenopause & USA & 1998-2011 & $27-44$ y & $2,833 / 1,725,295$ & $\begin{array}{l}\text { Q5:27.5; } \\
\text { Q1:11.1 }\end{array}$ & $\begin{array}{l}0.81 \\
(0.72-0.91)\end{array}$ & $\begin{array}{l}\text { Adolescent alcohol intake, adolescent energy } \\
\text { intake }\end{array}$ \\
\hline
\end{tabular}

USA: the United States of America, BMI: body mass index, CI: confidence interval, HRT: Hormone-replacement therapy, PMH: postmenopausal hormone, RR: relative risk, Null: not given; Q: quintile

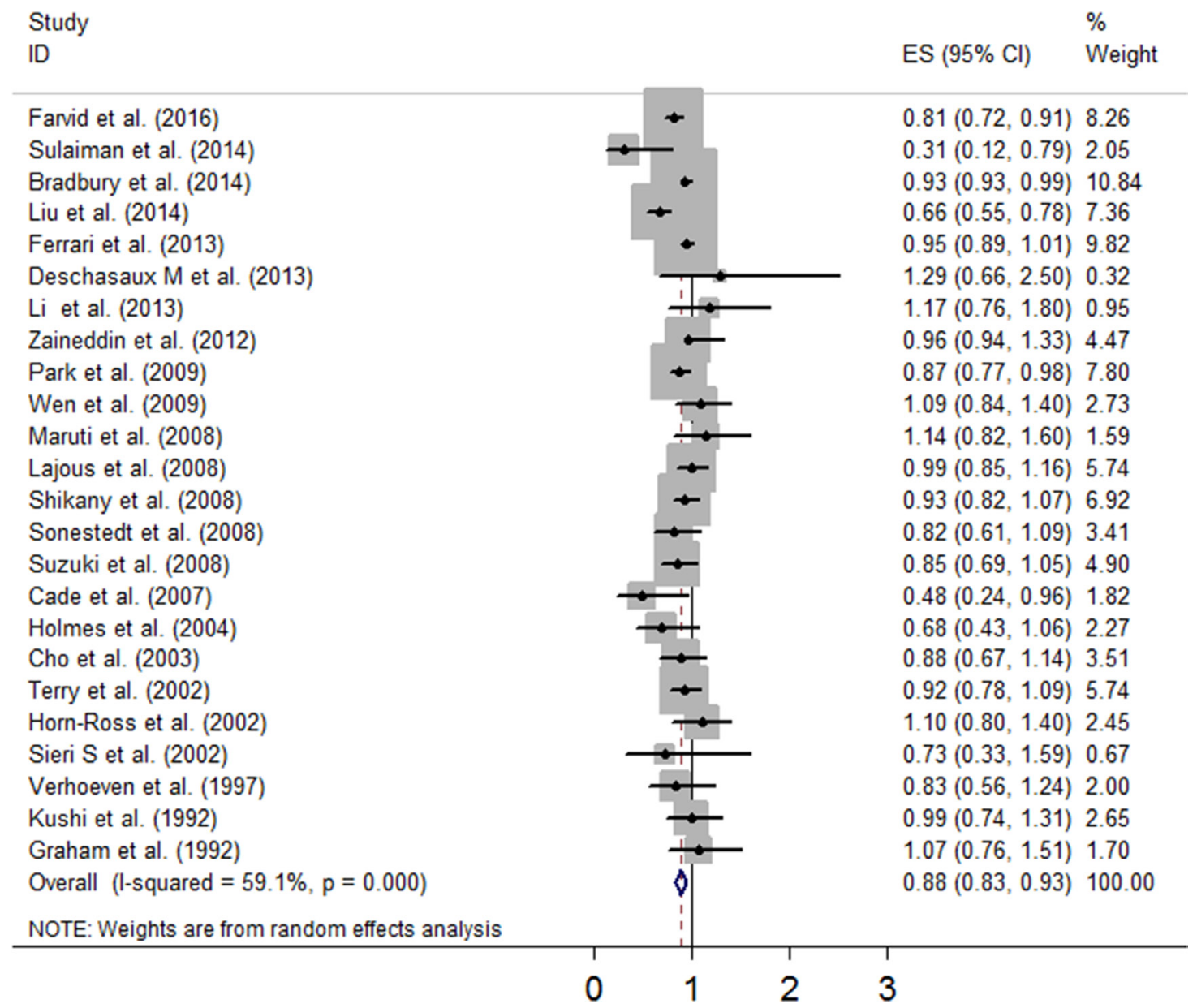

Figure 2: Forest plot of studies evaluating the association between dietary fibre intake and risk of breast cancer. 
Table 2: Stratified analysis of breast cancer risk in relation to dietary fibre intake according to study characteristics

\begin{tabular}{|c|c|c|c|c|}
\hline Group & No. of studies & RR (95\% CI) & $\boldsymbol{P}_{\text {heterogeneity }}$ & $I_{2}(\%)$ \\
\hline \multicolumn{5}{|l|}{ Menopausal status } \\
\hline $\begin{array}{l}\text { Premenopause } \\
\text { Postmenopause } \\
\text { Not specified }\end{array}$ & $\begin{array}{c}3 \\
10 \\
11\end{array}$ & $\begin{array}{l}0.78(0.62-0.94) \\
0.88(0.79-0.97) \\
0.92(0.84-0.99)\end{array}$ & $\begin{array}{l}0.172 \\
0.027 \\
0.016\end{array}$ & $\begin{array}{l}43.2 \\
52.1 \\
54.2\end{array}$ \\
\hline \multicolumn{5}{|l|}{ Jadad score } \\
\hline $\begin{array}{l}3 \\
4 \\
5\end{array}$ & $\begin{array}{c}6 \\
10 \\
8\end{array}$ & $\begin{array}{c}0.82(0.64-0.99) \\
0.96(0.88,1.03) \\
0.85(0.77,0.93)\end{array}$ & $\begin{array}{c}0.014 \\
0.796 \\
0\end{array}$ & $\begin{array}{c}65.1 \\
0 \\
76.9\end{array}$ \\
\hline \multicolumn{5}{|l|}{ IF } \\
\hline $\begin{array}{l}>3 \\
3\end{array}$ & $\begin{array}{c}21 \\
3\end{array}$ & $\begin{array}{l}0.89(0.83-0.94) \\
0.77(0.48,1.07)\end{array}$ & $\begin{array}{l}0.002 \\
0.002\end{array}$ & $\begin{array}{l}54.1 \\
83.8\end{array}$ \\
\hline \multicolumn{5}{|l|}{ Study types } \\
\hline $\begin{array}{l}\text { Cohort } \\
\text { Case-control }\end{array}$ & $\begin{array}{c}20 \\
4\end{array}$ & $\begin{array}{l}0.91(0.87,0.95) \\
0.75(0.47-1.02)\end{array}$ & $\begin{array}{l}0.210 \\
0.001\end{array}$ & $\begin{array}{l}19.6 \\
80.6\end{array}$ \\
\hline \multicolumn{5}{|l|}{ Geographic region } \\
\hline $\begin{array}{l}\text { Developed countries } \\
\text { Developing countries }\end{array}$ & $\begin{array}{c}22 \\
2\end{array}$ & $\begin{array}{l}0.89(0.84,0.94) \\
0.71(0.66-1.47)\end{array}$ & $\begin{array}{c}0.004 \\
0\end{array}$ & $\begin{array}{l}50.4 \\
91.8\end{array}$ \\
\hline
\end{tabular}

IF, influence factor; No., Number; RR, relative risk; CI, confidence interval.

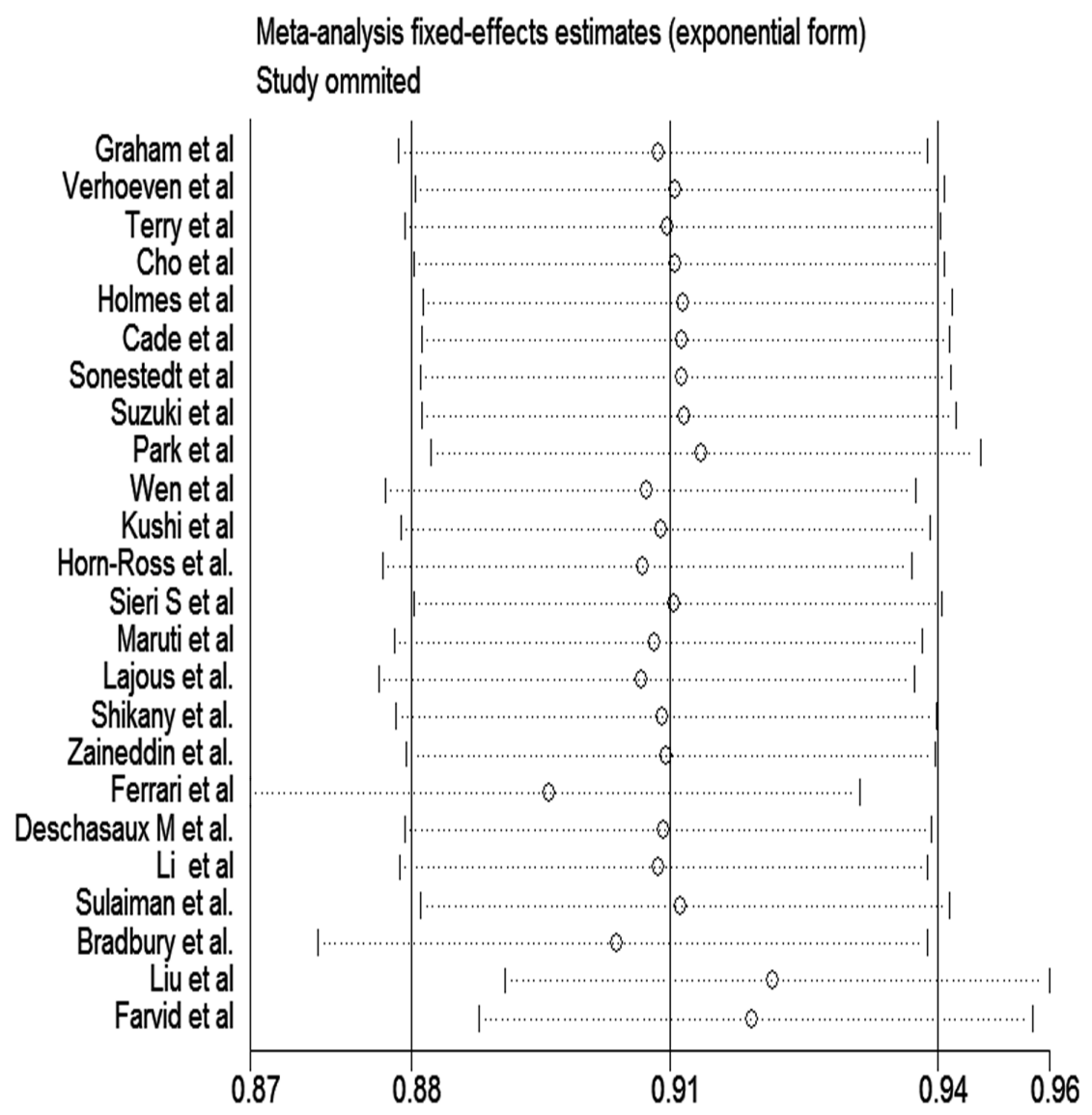

Figure 3: Sensitivity analysis of dietary fibre intake and risk of breast cancer. 


\section{DISCUSSION}

This manuscript aimed to clarify the association between dietary fibre intake and the risk of breast cancer. Our analyses showed a protective association between dietary fibre intake and breast cancer risk, and the risk could reduce by $12 \%$ on our result. Furthermore, an increment of every $10 \mathrm{~g} / \mathrm{d}$ increment of dietary fibre intake was associated with risk reduction of $4 \%$.

The size of heterogeneity may be the focus of Meta analysis. In this study, the heterogeneity can be partially explained by these facts: all included studies were conducted in Western countries except two [21, 27], there are many similarities in the population, such as genetic background, dietary patterns, lifestyle. One possible explanation for the heterogeneity is that the source of dietary fibre in each article was different. Moreover, we cannot rule out other good lifestyle habits of participants, which could prevent breast cancer.

The results from our subgroup and sensitivity analyses were strong, which was not significant associated with the geographic region, influence factor of studies, Jadad score, study types, or menopause status. A significant negative correlation between dietary fibre intake and breast cancer risk was observed in many subgroups, for example, postmenopause women, those with a Jadad score of 3 and 5, developed countries, developing countries, influence factor over 3 or lower than 3, and in case-control studies. Estrogen may have different metabolic pathways in premenopausal and postmenopausal women [31], no link was observed in the premenopausal women, probably due to a small number of studies $(n=3)$ included in this meta-analysis, yielding a low statistical power [32, 33]. In addition, several studies are different from some aspects of others. For instance, the French cohort [19], which started in 1993, only adjusted for total energy intake. On the other hand, the US cohort [7], which adjustment factors was too few, and the Italian cohort [12], which started in 1987, the range of the highest and lowest dietary fibre intake was relatively narrow ( $20.1 \mathrm{~g} / \mathrm{d}$ vs. $16.6 \mathrm{~g} / \mathrm{d}$, respectively).

The following mechanisms may explain the inverse association between dietary fibre intake and breast cancer risk. Dietary fibre is composed of a variety of monomers forming carbohydrate polymers, which cannot be digested and absorbed by the small intestinal in the human body. These polymers mainly include cellulose, hemicellulose, pectin, hydrophilic colloid substances, lignin from plant cell walls, and other components that cannot be degraded by human digestive enzymes [34, 35]. These components of dietary fibre not only absorb and retain moisture, but more importantly, combine with harmful and carcinogenic substances in the gut and promote their discharge and decomposition [36]. Further, dietary fibre can promote the growth of probiotics and inhibit the growth of pathogenic bacteria, thereby inhibiting production of carcinogens and promoting their decomposition in the intestine. It also improves the phagocytosis of macrophages, blocks nitrosamine synthesis, and reduces oestrogen levels. Dietary fibre can also promote the short-chain fatty acids (SCFAs) produced by bacterial fermentation in the colon. Studies have shown that SCFAs are closely associated with tumour development. SCFAs can inhibit the antiapoptotic gene bcl-2 and promote expression of the proapoptotic gene bax. As such, dietary fibre promotes cell

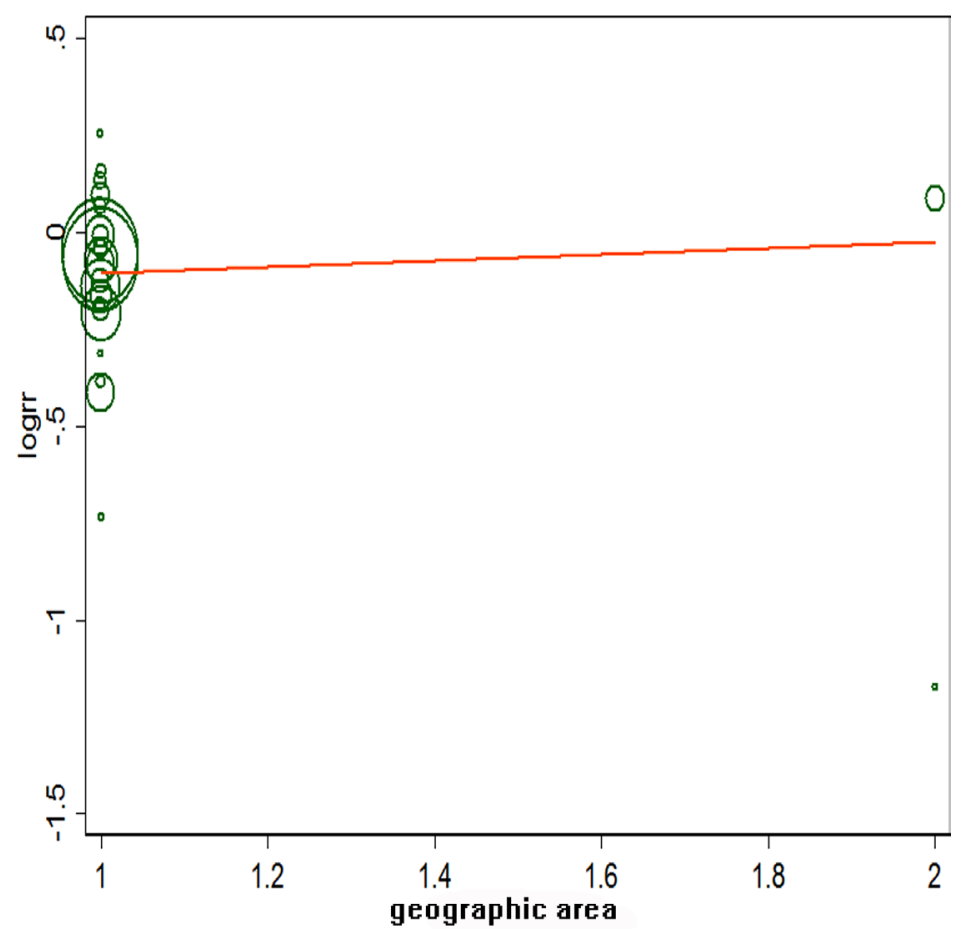

Figure 4: Meta regulation of geographic area and risk of breast cancer. 
apoptosis, thereby preventing development of cancer [37]. Dietary fibre has important physiological functions such as adsorption of ions and organic compounds as well as free oestrogen formed by human intestinal microbial enzymes, which may reduce the risk of breast cancer. Dietary fibre may also have the function of controling the insulin-like growth factors and insulin resistance, thereby protecting against type 2 diabetes mellitus [38]. These factors may also affect the occurrence of breast cancer [39, 40]. Food rich in dietary fibre is known to have a protective effect

Begg's funnel plot with pseudo $95 \%$ confidence limits

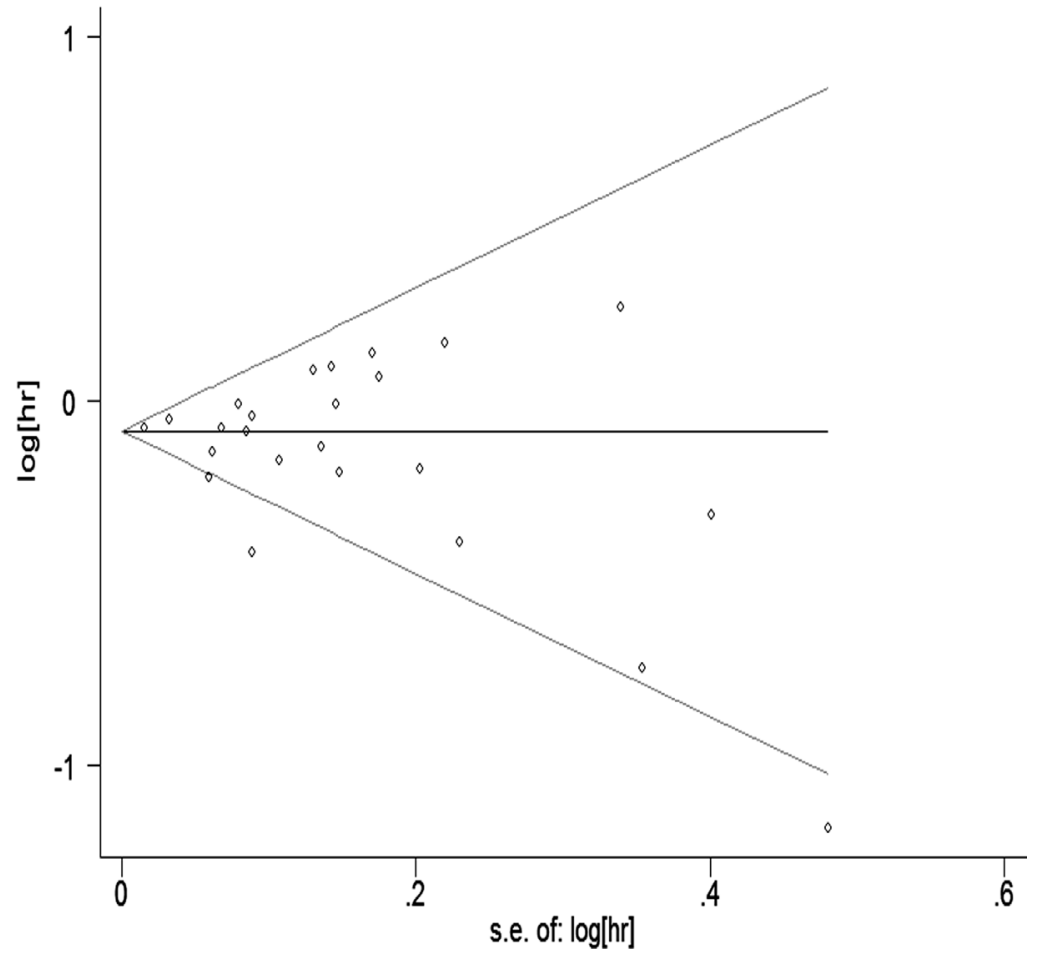

Figure 5: Begger's funnel plot assessing publication bias among studies.

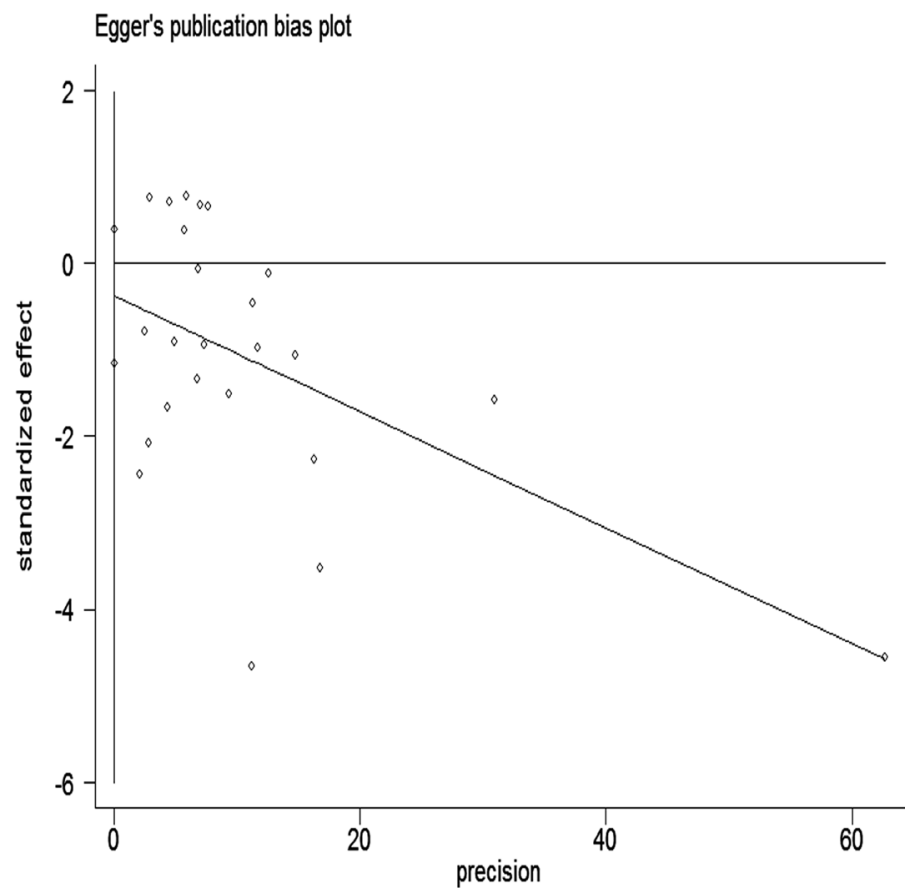

Figure 6: Egger's funnel plot assessing publication bias among studies. 
on breast cancer, and with an increase in consumption of dietary fibre, its protective effect is enhanced. This may be because the fibre can reduce the level of female mammary hormones in the blood, which reduces the occurrence of breast carcinoma [41]. Currently, evidence on dietary fibre is limited, and therefore, future studies concerning the factors in dietary fibre that influence the risk of breast cancer are needed.

Our study has strengths. Our meta-analysis involved enlarged number of studies and participants to date. Besides, we conducted the dose-response analysis to quantify the relationships between dietary fibre intakes and risk of breast cancer.

Despite our important findings, there were a few potential limitations that should be noted. First, unmeasured or uncontrolled confounders should always be accounted for in the selected studies (for example, genic mutation, pecuniary condition). Although most of the studies have an extensive coverage of adjustment, while other residual confounding factors should be considered for further investigation. Second, random errors in dietary fibre intake may have an effect on the outcome, which is inevitable. Third, due to the current articles were mainly based on data from Europe and the United States, our hierarchical analysis shows that geographical changes in a large extent contributed to the substantial heterogeneity.

Our results have a guiding significance in breast cancer. Worldwide, the most common cancer in women remains breast carcinoma, after years of medical development, the 5 year survival rate of breast cancer is not high. Moreover, in some European regions and the United States the intake of dietary fibre are about $22 \mathrm{~g} / \mathrm{day}$, this is far below the recommended intake [42]. The existing data are inconsistent from selected studies. Therefore, the clarification of this issue in this study was both important and timely.

In summary, this meta-analysis of epidemiological studies demonstrates that dietary fibre intake was associated with a significant dose response relationship between breast cancer risk and breast cancer risk. Due to the large burden and high incidence of breast cancer, measures for prevention of breast cancer are necessary, and increasing the dietary fibre intake in the diet of the general population may have important prevention of breast cancer.

\section{MATERIALS AND METHODS}

\section{Literature search}

We performed a systematic search for relevant publications by searching PubMed (http://www.ncbi.nlm. nih.gov/pubmed/), Embase (http:/www.embase.com/), Web of Science (http://wokinfo.com/), and the Cochrane Library (http://www.the cochrane library.com/) databases through March 2016. Both case-control and cohort studies published in the English language were searched for using the search terms 'dietary fibre OR fibre OR fibre' and 'breast cancer OR breast neoplasms'. In addition, we manually searched through the reference lists of original articles, recent reviews, and meta-analyses. However, we did not contact the authors for the unpublished studies.

\section{Study selection}

Studies fulfilling the following criteria were included in our analysis: (1) the exposure of interest was intake of total dietary fibre; (2) the endpoint was breast cancer incidence; (3) the study design was prospective, i.e. cohort or case-control study; and (4) the relative risk (RR) and corresponding 95\% confidence interval (CI) values were reported for the highest and lowest categories of dietary fibre intake. If the same population was considered in more than one study, we included the study with the maximally adjusted model.

\section{Data extraction and quality assessment}

We recorded the following study characteristics: (1) last name of the first author; (2) publication year; (3) menopause status; (4) geographic area; (5) duration; (6) age range; (7) no. of cases/sample size; (8) exposure range (total dietary fibre intake expressed uniformly as g/d); (9) RR from the most fully adjusted model for the highest and lowest dietary fibre intake and the corresponding 95\% CI; (10) adjustment for potential confounders in multivariate analysis; and (11) the Jadad score, a scale used to measure the quality of each trial, which ranges from 0 to 5 according to the descriptions of randomisation, blinding, and reporting of participant withdrawals [43].

\section{Statistical analyses}

Incidence rate and hazard ratios ratios were deemed as RR. In highest and lowest categories of dietary fibre intake in meta-analyses, the RR estimate from each study was weighted by the inverse of the variance to calculate RR and 95\% CI. We calculated the $Q$ and $I^{2}$ statistics to examine statistical heterogeneity across studies [44]. A random-effects models [45] was used to calculate the combined RR. Results from the random-effects model, which considered both within- and between-study variations [45], were noted. A sensitivity analysis was conducted using random-effects models to evaluate the robustness of the results.

Pre-specified subgroup analyses were performed according to geographic regions, influence factor of the studies, study types, Jadad scores, and menopause status to assess the potential effect modification of these variables on outcomes. We conducted a sensitivity analysis to investigate the influence of a single study on the overall risk estimate by omitting one study in each 
turn. In addition, we performed meta-regression analyses to explore the possible explanations for heterogeneity among trials.

To quantify the dose-response relationship between dietary fibre intakes and breast cancer incidence, we conducted a dose-response analysis based on data for different categories of the average dietary fibre dose [46]. Studies were excluded if the required data were not reported or could not be estimated.

To determine the presence of any publication bias, we performed both Egger's and Begg's tests [47], and inspected the funnel plots. All analyses were performed using STATA version 13.0. Values of $P<0.05$ were considered statistically significant, unless otherwise specified.

\section{ACKNOWLEDGMENTS}

We would like to thank the native English speaking scientists of Elixigen Company (Huntington Beach, California) for editing our manuscript.

\section{CONFLICTS OF INTEREST}

The authors report no conflicts of interests. We confirm that none of the authors are related to authors of studies included in the meta-analysis.

\section{Authors' contributions}

Sumei Chen and Yuanyuan Chen were responsible for the study design, data acquisition, statistical analysis, and the interpretation of the results. Shenglin Ma, Ruzhen Zheng, Pengjun Zhao, Lidan Zhang, Yuehua Liu and Qingqing Yu wrote the manuscript. Qinghua Deng and Ke Zhang critically reviewed the manuscript for important intellectual content and approved the final manuscript.

\section{REFERENCES}

1. Willett WC, MacMahon B. Diet and cancer-an overview (second of two parts). N Engl J Med. 1984; 310:697-703.

2. Cummings JH, Bingham SA. Diet and the prevention of cancer. BMJ. 1998; 317:1636-1640.

3. Willett WC. Diet and breast cancer. J Intern Med. 2001; 249:395-411.

4. Key TJ, Verkasalo PK, Banks E. Epidemiology of breast cancer. Lancet Oncol. 2001; 2:133-140.

5. Goldin BR, Adlercreutz H, Gorbach SL, Warram JH, Dwyer JT, Swenson L, Woods MN. Estrogen excretion patterns and plasma levels in vegetarian and omnivorous women. N Engl J Med. 1982; 307:1542-1547.

6. Aune D, Chan DS, Greenwood DC, Vieira AR, Rosenblatt DA, Vieira R, Norat T. Dietary fibre and breast cancer risk: a systematic review and meta-analysis of prospective studies. Ann Oncol. 2012; 23:1394-1402.
7. Graham S, Zielezny M, Marshall J, Priore R, Freudenheim J, Brasure J, Haughey B, Nasca P, Zdeb M. Diet in the epidemiology of postmenopausal breast cancer in the New York State Cohort. Am J Epidemiol. 1992; 136:1327-1337.

8. Kushi LH, Sellers TA, Potter JD, Nelson CL, Munger RG, Kaye SA, Folsom AR. Dietary fat and postmenopausal breast cancer. J Natl Cancer Inst. 1992; 84:1092-1099.

9. Verhoeven DT, Assen N, Goldbohm RA, Dorant E, van 't Veer P, Sturmans F, Hermus RJ, van den Brandt PA. Vitamins $\mathrm{C}$ and $\mathrm{E}$, retinol, beta-carotene and dietary fibre in relation to breast cancer risk: a prospective cohort study. Br J Cancer. 1997; 75:149-155.

10. Terry P, Jain M, Miller AB, Howe GR, Rohan TE. No association among total dietary fibre, fibre fractions, and risk of breast cancer. Cancer Epidemiol Biomarkers Prev. 2002; 11:1507-1508.

11. Horn-Ross PL, Hoggatt KJ, West DW, Krone MR, Stewart SL, Anton H, Bernstei CL, Deapen D, Peel D, Pinder R, Reynolds P, Ross RK, Wright W, et al. Recent diet and breast cancer risk: the California Teachers Study (USA). Cancer Causes Control. 2002; 13:407-415.

12. Sieri S, Krogh V, Muti P, Micheli A, Pala V, Crosignani P, Berrino F. Fat and protein intake and subsequent breast cancer risk in postmenopausal women. Nutr Cancer. 2002; 42:10-17.

13. Cho E, Spiegelman D, Hunter DJ, Chen WY, Colditz GA, Willett WC. Premenopausal dietary carbohydrate, glycemic index, glycemic load, and fibre in relation to risk of breast cancer. Cancer Epidemiol Biomarkers Prev. 2003; 12: 1153-1158.

14. Holmes MD, Liu S, Hankinson SE, Colditz GA, Hunter DJ, Willett WC. Dietary carbohydrates, fibre, and breast cancer risk. Am J Epidemiol. 2004; 159:732-739.

15. Cade JE, Burley VJ, Greenwood DC. Dietary fibre and risk of breast cancer in the UK Women's Cohort Study. Int J Epidemiol. 2007; 36:431-438.

16. Sonestedt E, Borgquist S, Ericson U, Gullberg B, Landberg G, Olsson H, Wirfält E. Plant foods and oestrogen receptor alpha- and beta-defined breast cancer: observations from the Malmo Diet and Cancer cohort. Carcinogenesis. 2008; 29:2203-2209.

17. Suzuki R, Rylander-Rudqvist T, Ye W, Saji S, Adlercreutz H, Wolk A. Dietary fibre intake and risk of postmenopausal breast cancer defined by estrogen and progesterone receptor status-a prospective cohort study among Swedish women. Int J Cancer. 2008; 122:403-412.

18. Maruti SS, Lampe JW, Potter JD, Ready A, White E. A prospective study of bowel motility and related factors on breast cancer risk. Cancer Epidemiol Biomarkers Prev. 2008; 17:1746-1750.

19. Lajous M, Boutron-Ruault MC, Fabre A, Clavel-Chapelon F, Romieu I. Carbohydrate intake, glycemic index, glycemic load, and risk of postmenopausal breast cancer in a prospective study of French women. Am J Clin Nutr. 2008; 87:1384-1391. 
20. Park Y, Brinton LA, Subar AF, Hollenbeck A, Schatzkin A. Dietary fibre intake and risk of breast cancer in postmenopausal women: the National Institutes of HealthAARP Diet and Health Study. Am J Clin Nutr. 2009: 90;664-671.

21. Wen W, Shu XO, Li H, Yang G, Ji BT, Cai H, Gao YT, Zheng W. Dietary carbohydrates, fibre, and breast cancer risk in Chinese women. Am J Clin Nutr. 2009; 89: 283-289.

22. Shikany JM, Redden DT, Neuhouser ML, Chlebowski RT, Rohan TE, Simon MS, Liu S, Lane DS, Tinker L. Dietary glycemic load, glycemic index, and carbohydrate and risk of breast cancer in the Women's Health Initiative. Nutr Cancer. 2011; 63:899-907.

23. Zaineddin AK, Buck K, Vrieling A, Heinz J, Flesch-Janys D, Linseisen J, Chang-Claude J. The association between dietary lignans, phytoestrogen-rich foods, and fibre intake and postmenopausal breastcancer risk: a German casecontrol study. Nutr Cancer. 2012; 64:652-665.

24. Ferrari P, Rinaldi S, Jenab M, Lukanova A, Olsen A, Tjønneland A, Overvad K, Clavel-Chapelon F, Fagherazzi G, Touillaud M, Kaaks R, von Rüsten A, Boeing H, et al. Dietary fibre intake and risk of hormonal receptor-defined breast cancer in the European Prospective Investigationinto Cancer and Nutrition study. Am J Clin Nutr. 2013; 97: 344-353.

25. Deschasaux M, Zelek L, Pouchieu C, His M, Hercberg S, Galan P, Latino-Martel P, Touvier M. Prospective association between dietary fibre intake and breast cancer risk. PLoS One. 2013; 8:e79718.

26. Li Q, Holford TR, Zhang Y, Boyle P, Mayne ST, Dai M, Zheng T. Dietary fibre intake and risk of breast cancer by menopausal and estrogen receptor status. Eur J Nutr. 2013; 52:217-223.

27. Sulaiman S, Shahril MR, Wafa SW, Shaharudin SH, Hussin SN. Dietary carbohydrate, fibre and sugar and risk of breast cancer according to menopausal status in Malaysia. Asian Pac J Cancer Prev. 2014; 15:5959-5964.

28. Bradbury KE, Appleby PN, Key TJ. Fruit, vegetable, and fibre intake in relation to cancer risk: findings from the European Prospective Investigationinto Cancer and Nutrition (EPIC). Am J Clin Nutr. 2014; 394S-3948S.

29. Liu Y, Colditz GA, Cotterchio M, Boucher BA, Kreiger N. Adolescent dietary fibre, vegetable fat, vegetable protein, and nut intakes and breast cancer risk. Breast Cancer Res Treat. 2014; 145:461-470.

30. Farvid MS, Eliassen AH, Cho E, Liao X, Chen WY, Willett WC. Dietary Fibre Intake in Young Adults and Breast Cancer Risk. Pediatrics. 2016; 137:1-11.

31. Jadad AR, Moore RA, Carroll D, Jenkinson C, Reynolds DJ, Gavaghan DJ, McQuay HJ. Assessing the quality of reports of randomized clinical trials: is blinding necessary? Control Clin Trials. 1996; 17:1-12.

32. Freudenheim JL, Marshall JR, Vena JE, Laughlin R, Brasure JR, Swanson MK, Nemoto T, Graham S. Premenopausal breast cancer risk and intake of vegetables, fruits, and related nutrients. J Natl Cancer Inst. 1996; 88:340-348.

33. La Vecchia C, Ferraroni M, Franceschi S, Mezzetti M, Decarli A, Negri E. Fibres and breast cancer risk. Nutr Cancer. 1997; 28:264-269.

34. Higgins JP, Thompson SG. Quantifying heterogeneity in a meta-analysis. Stat Med. 2002; 21:1539-1558.

35. DerSimonian R, Laird N. Meta-analysis in clinical trials. Control Clin Trials. 1986; 7:177-188.

36. Levy J, Fabian MP, Peters JL. Meta-Analytic Approaches for Multistressor Dose-Response Function Development: Strengths, Limitations, and Case Studies. Risk Anal. 2015; 35:1040-1049.

37. Begg CB, Mazumdar M. Operating characteristics of a rank correlation test for publication bias. Biometrics. 1994; 50:1088-1101.

38. Dallal CM, Lacey JV Jr, Pfeiffer RM, Bauer DC, Falk RT, Buist DS, Cauley JA, Hue TF, LaCroix AZ, Tice JA, Veenstra TD, Xu X, Brinton LA, et al. Estrogen Metabolism and Risk of Postmenopausal Endometrial and Ovarian Cancer: the B<FIT Cohort. Horm Cancer. 2016; 7:49-64.

39. Cummings JH, Mann JI, Nishida C, Vorster HH. Dietary fibre: an agreed definition. Lancet. 2009; 373:365-366.

40. Kunzmann AT, Coleman HG, Huang WY, Kitahara CM, Cantwell MM, Berndt SI. Dietary fibre intake and risk of colorectal cancer and incident and recurrent adenoma in the Prostate, Lung, Colorectal, and Ovarian Cancer Screening Trial. Am J Clin Nutr. 2015; 102:881-890.

41. Rock CL, Flatt SW, Thomson CA, Stefanick ML, Newman VA, Jones LA, Natarajan L, Ritenbaugh C, Hollenbach KA, Pierce JP, Chang RJ. Effects of a highfibre, low-fat diet intervention on serum concentrations of reproductive steroid hormones in women with a history of breast cancer. J Clin Oncol. 2004; 22:2379-2387.

42. Cohen LA. Dietary fibre and breast cancer. Anticancer Res. 1999; 19:3685-3588.

43. Larsson SC, Mantzoros CS, Wolk A. Diabetes mellitus and risk of breast cancer: a meta-analysis. Int J Cancer. 2007; 121:856-862.

44. Yu H, Rohan T. Role of the insulin-like growth factor family in cancer development and progression. J Natl Cancer Inst. 2000; 92:1472-1489.

45. Lawlor DA, Smith GD, Ebrahim S. Hyperinsulinaemia and increased risk of breast cancer: findings from the British Women's Heart and Health Study. Cancer Causes Control. 2004; 15:267-275.

46. Marlett JA, McBurney MI, Slavin JL. Position of the American Dietetic Association: health implications of dietary fibre. J Am Diet Assoc. 2002; 102:993-1000.

47. Chandalia M, Garg A, Lutjohann D, von Bergmann K, Grundy SM, Brinkley LJ. Beneficial effects of high dietary fibre intake in patients with type 2 diabetes mellitus. N Engl J Med. 2000; 342:1392-1398. 